\title{
GnRH mRNA Increases with Puberty in the Male Syrian Hamster Brain
}

\author{
D. B. Parfitt,* R. C. Thompson, † H. N. Richardson, *R. D. Romeo* and C. L. Sisk* \\ *Neuroscience Program, Department of Psychology, Michigan State University, East Lansing, MI, USA. \\ $\dagger$ Reproductive Sciences Program, University of Michigan, Ann Arbor, MI, USA.
}

Key words: luteinizing hormone releasing hormone, puberty, diagonal band of Broca, medial septum, preoptic area, in-situ hybridization.

\begin{abstract}
Puberty in the male Syrian hamster (Mesocricetus auratus) is characterized by decreased responsiveness to testosterone mediated negative feedback, but the neural mechanism for this change remains elusive. We hypothesized that decreased inhibition of the gonadotropin-releasing hormone $(\mathrm{GnRH})$ system results in increased neurosecretory activity, which includes an increase in GnRH gene expression. This study examined GnRH mRNA in male hamsters before and after puberty, and sought to determine if any increase in mRNA was specific to particular subpopulations of GnRH neurones. Brains were collected from 21-day-old prepubertal males $(n=5)$ and 56-day-old postpubertal males $(n=5)$. Alternate $10 \mu \mathrm{m}$ coronal sections from fresh-frozen brains were collected throughout the septo-hypothalamic region, and $25 \%$ of those sections were processed for in-situ hybridization histochemistry using an ${ }^{35} \mathrm{~S}$-riboprobe complementary to hamster GnRH. No differences were observed in the number of GnRH mRNA expressing cells in any region, but in the diagonal band of Broca (DBB)/organum vasculosum of the lamina terminalis (OVLT) there was a significant increase in labelling intensity (defined as area of the cell occupied by silver grains) in postpubertal males. A second analysis compared the frequency distributions of cells based on labelling intensity between prepubertal and postpubertal males. This analysis revealed significant differences between the two frequency distributions in all areas analysed (DBB/OVLT, medial septum (MS), and preoptic area (POA)). Furthermore, examining the distribution of cells in these regions revealed a shift to the right in the postpubertal population of cells, which indicated an increased number of $\mathrm{GnRH}$ neurones with greater labelling intensity. These data clearly demonstrate increased $\mathrm{GnRH}$ mRNA during puberty. Furthermore, they suggest that the previous observation of brain region specific pubertal decreases in GnRH-immunoreactivity only within the DBB/OVLT and MS but not the POA are not due to differential levels of $\mathrm{GnRH}$ gene expression, but could indicate increased release from these neurones during puberty.
\end{abstract}

In the male Syrian hamster (Mesocricetus auratus), the onset of puberty is characterized by a striking decrease in the response to steroid negative feedback regulation of gonadotropin secretion. In the gonad-intact juvenile, circulating levels of luteinizing hormone $(\mathrm{LH})$ and follicle stimulating hormone $(\mathrm{FSH})$ are low and increase at the time of puberty $(1,2)$. If testosterone $(\mathrm{T})$ levels are held constant in a castrated T-replaced juvenile male hamster, LH and follicle stimulating hormone (FSH) levels remain low until the onset of puberty when they begin to increase independently of any change in $\mathrm{T}$ levels (1). These data demonstrate a pubertal escape from testosterone mediated inhibition of gonadotropin secretion. While this pubertal decrease in responsiveness to testosterone has been well characterized in the hamster and in other species $(3,4)$, the neural mechanisms governing this change remain poorly understood.

Gonadotropin secretion is controlled by gonadotropin releasing hormone $(\mathrm{GnRH})$ neurones, which project to the hypophyseal portal vasculature located in the median eminence (5). These neurones originate in the embryonic olfactory placode and migrate to their final destination in the mature brain (5). However, this final destination is not confined to a single nucleus in the brain, but instead comprises a diffuse network of GnRH cells distributed throughout the rostralcaudal extent of the forebrain. In the hamster, GnRH neurones are found as far rostral as the anterior olfactory nucleus

Correspondence to: Cheryl L. Sisk, Neuroscience Program, Department of Psychology, Michigan State University, East Lansing, MI 48824, USA (e-mail: sisk@pilot.msu.edu).

(C) 1999 Blackwell Science Ltd 
and extend as far caudal as the arcuate nucleus $(6,7)$. However, the vast majority $(>90 \%)$ of $\mathrm{GnRH}$ cells are located within three distinct subpopulations: the diagonal band of Broca (DBB)/organum vasculosum of the lamina terminalis (OVLT), the medial septum (MS), and the preoptic area $(\mathrm{POA})(6,7)$.

Recent evidence in both the male Syrian hamster and European ferret (Mustela putorius furo) suggests that specific subpopulations of $\mathrm{GnRH}$ neurones are active at the onset of puberty. When immunocytochemistry was used to identify GnRH-immunoreactive (GnRH-ir) neurones, a decrease in the number of GnRH-ir neurones was observed exclusively in the DBB/OVLT and MS of adult compared to prepubertal male hamsters (7). Similarly, fewer numbers of GnRH-ir cells were observed in the arcuate nucleus of adult male ferrets $v s$ juveniles (8). In both species, a decrease in GnRH-ir cells was not observed in other populations of GnRH neurones. This change in immunoreactivity could result from reduced somal stores of GnRH protein as a consequence of increased GnRH release. Furthermore, examination of the pubertal regulation of GnRH mRNA in the male ferret using in-situ hybridization revealed an increase in the number of labelled cells in the arcuate nucleus of adult compared to prepubertal animals (9). While increases in mRNA do not necessarily reflect changes in biosynthesis, this result could indicate increased $\mathrm{GnRH}$ synthesis as a result of increased $\mathrm{GnRH}$ release. Taken together, these data suggest that populations of GnRH neurones in the hamster DBB/OVLT and MS and ferret arcuate nucleus are specifically affected by the pubertal decrease in steroid negative feedback, thereby mediating the pubertal increase in gonadotropin secretion.

The purpose of this study was twofold. First, this study determined if GnRH mRNA increases during pubertal development of the male hamster. Second, this study asked the following question: is the pubertal decrease in the number of GnRH-ir cells within the DBB/OVLT and MS mirrored by increased GnRH mRNA in these regions and thus reflective of increased GnRH release? For both of these objectives, we hypothesized that specific populations of GnRH neurones in the DBB/OVLT and MS mediate the pubertal increase in GnRH secretion, and therefore predicted that expression of GnRH mRNA within these regions would be greater in adults compared to juveniles. To test this hypothesis, in-situ hybridization for detection of GnRH mRNA was used to quantify both the number of GnRH cells and the amount of GnRH mRNA within those cells in the hamster brain before and after puberty.

\section{Materials and methods}

\section{Animals}

Eighteen-day-old male Syrian hamsters (M. auratus) and their mothers were purchased from Charles River (Cambridge, MA, USA). All animals were weaned from their mothers at 20 days of age and grouped housed three/cage in clear polycarbonate cages $(37.5 \times 33 \times 17 \mathrm{~cm})$ under constant temperature $\left(21 \pm 2{ }^{\circ} \mathrm{C}\right)$ and long-day photoperiod $(14 \mathrm{~h}$ light:10 $\mathrm{h}$ dark; lights on at $06.00 \mathrm{~h}$ EST). Throughout the experiment, animals had ad libitum access to food (Teklad Rodent Diet no. 8640, Harlan, Madison, WI, USA) and water. All animals were treated in accordance with the NIH Guide for the Care and Use of Laboratory Animals, and all procedures were approved by the
Michigan State University All-University Committee for Animal Use and Care.

Blood and tissue collection

At either 21 (prepubertal; $\mathrm{n}=5$ ) or 56 (postpubertal; $\mathrm{n}=5$ ) days of age, animals were weighed, briefly anaesthetized with methoxyflurane (Metofane, Mallinckrodt Veterinary Inc., Mundelein, IL, USA), and killed by decapitation. Trunk blood was collected into heparinized tubes for determination of plasma testosterone concentration. Brains were rapidly removed, frozen on dry ice, and stored at $-80^{\circ} \mathrm{C}$ prior to sectioning. In addition, paired testis and seminal vesicles were dissected and weighed. All procedures were conducted between 09.00 and $12.00 \mathrm{~h}$.

\section{Testosterone radioimmunoassay}

Circulating plasma testosterone concentrations were determined using the Coat-A-Count Total Testosterone Kit (Diagnostic Products, Los Angeles, CA, USA). All samples were run in a single assay with a sensitivity of $0.2 \mathrm{ng} / \mathrm{ml}$ and intra-assay variability of $5.7 \%$. To validate this assay for testosterone measurement in the Syrian hamster, samples from intact and castrate male hamster pools were assayed at five different dilutions. These results were compared to a standard curve generated from human serumbased calibrators included in the kit and having testosterone concentrations ranging from 0.2 to $16 \mathrm{ng} / \mathrm{ml}$. Testosterone values obtained from the diluted intact and castrate hamster pools were parallel to the internal standard curve and maintained linearity throughout its reported range.

\section{In-situ hybridization}

Coronal brain sections $(10 \mu \mathrm{m})$ were cut on a cryostat, and alternate sections were collected onto four sets of poly-lysine subbed slides and stored at $-80^{\circ} \mathrm{C}$ until further processing. In-situ hybridization was conducted using a modification of previously described techniques (10). For each animal, one set of sections was removed from the freezer and immediately placed into $4 \%$ paraformaldehyde for $60 \mathrm{~min}$ at room temperature. Following washes in $2 \times \mathrm{NaCl} / \mathrm{Na}$ citrate (SSC), sections were placed for $10 \mathrm{~min}$ in $0.1 \mathrm{M}$ triethanolamine to which $0.25 \%$ acetic anhydride had been added. Sections were then thoroughly washed with distilled water, and dehydrated through a series of graded alcohols.

The ${ }^{35} \mathrm{~S}$-labelled cRNA probe for $\mathrm{GnRH}$ was generated from cDNA subcloned in a pCRII vector using standard in-vitro transcription methodology. The hamster GnRH cDNA clone (courtesy of Dr Heiko Jansen, University of Cincinnati) yielded a 298 -bp cRNA probe. The antisense probe was labelled in a reaction mixture consisting of $1 \mu \mathrm{g}$ of linearized DNA (BamH I linearized plasmid), $5 \times$ transcription buffer (Epicentre Technologies, Madison, WI, USA), $80 \mu \mathrm{Ci}\left[{ }^{35} \mathrm{~S}\right] \mathrm{UTP}, 120 \mu \mathrm{Ci}\left[{ }^{35} \mathrm{~S}\right] \mathrm{CTP}, 150 \mu \mathrm{M}$ each of ATP and GTP, $12.5 \mathrm{mM}$ dithiothreitol, $20 \mathrm{U}$ RNase inhibitor, and $6 \mathrm{U}$ T7 RNA polymerase (Epicentre Technologies). The reaction was incubated for $2 \mathrm{~h}$ at $37^{\circ} \mathrm{C}$, and the probe separated from unincorporated nucleotides over a Sephadex G50-50 column. As a control, a sense probe was labelled in an identical reaction mixture as described above except for using $1 \mu \mathrm{g}$ of linearized DNA (Xho I linearized plasmid) and 6 U SP6 RNA polymerase (Epicentre Technologies).

Both the antisense and sense probes were diluted in hybridization buffer (Amresco, Solon, OH, USA) to yield $\approx 1.0 \times 106$ d.p.m. $/ 60 \mu 1$ of buffer. Diluted probe $(60 \mu \mathrm{l})$ was applied to each slide and the sections coverslipped. Slides were then placed in sealed plastic boxes lined with filter paper moistened with $50 \%$ formamide. These boxes were wrapped with plastic wrap and incubated at $55^{\circ} \mathrm{C}$ for $16 \mathrm{~h}$. Following overnight incubation, coverslips were removed, and the slides washed in $2 \times$ SSC. Slides were then incubated in RNase A $(200 \mu \mathrm{g} / \mathrm{ml})$ at $37^{\circ} \mathrm{C}$ for $60 \mathrm{~min}$, washed successively in decreasing concentrations of SSC $(2 \times, 1 \times, 0.5 \times, 0.1 \times)$, and then washed in $0.1 \times$ SSC at $70{ }^{\circ} \mathrm{C}$ for $60 \mathrm{~min}$. Slides were subsequently rinsed in distilled water and dehydrated through graded alcohols. Next, slides were exposed to XAR film (Eastman Kodak, Rochester, NY, USA) for 7 days, and then dipped in NTB2 emulsion (Eastman Kodak), diluted 1:1 in distilled water, and stored at $4{ }^{\circ} \mathrm{C}$ for 3 days. Emulsion dipped slides were developed in D-19 developer (Eastman Kodak), counterstained with cresyl violet, dehydrated in a series of graded alcohols, placed in xylene, and coverslipped with Permount (Fisher Scientific, Pittsburgh, PA, USA). To allow reliable comparisons between groups, sections from both age groups were processed together.

\section{Microscopic analysis}

The pattern of GnRH mRNA expression over the course of puberty was characterized by microscopic examination of emulsion-dipped sections in 
three brain regions: the DBB/OVLT, MS, and POA. The anatomical boundaries for these regions are similar to those previously defined in this laboratory (Fig. 1). Furthermore, in the male hamster, $90 \%$ of the total number of GnRH-ir neurones reside within these three operationally defined brain regions (7). The method for quantifying the number of silver grains overlying a cresyl violet-stained cell and the number of GnRH mRNA expressing cells was adapted from previous reports (11) and performed in the following manner by an experimenter blind to the treatment groups. Using a Leitz Laborlux S microscope equipped with a CCD video camera (Sony, XC-77), images of lightly counterstained cells were captured at $40 \times$ through a blue no. 47 filter (Tiffen, Hauppauge, NY, USA), which effectively subtracted the Nissl stain, into a Power Macintosh 7100 computer. Cellular profiles were traced and area determinations made within NIH Image 1.57. Next, images were thresholded to visualize silver grains only, and area determinations repeated. The sampling template was then moved to an unhybridized region of tissue to establish the background silver grain area. This background grain area was subtracted from the silver grain area overlying the Nissl stained cell, and the results were expressed as area occupied by silver grains. Cells with more than $5 \times$ the area of silver grains when compared to the background area were classified as labelled.

\section{Data analysis}

The non-parametric Mann-Whitney $U$-test was utilized to determine significant differences between age groups in the mean physiological (body, paired

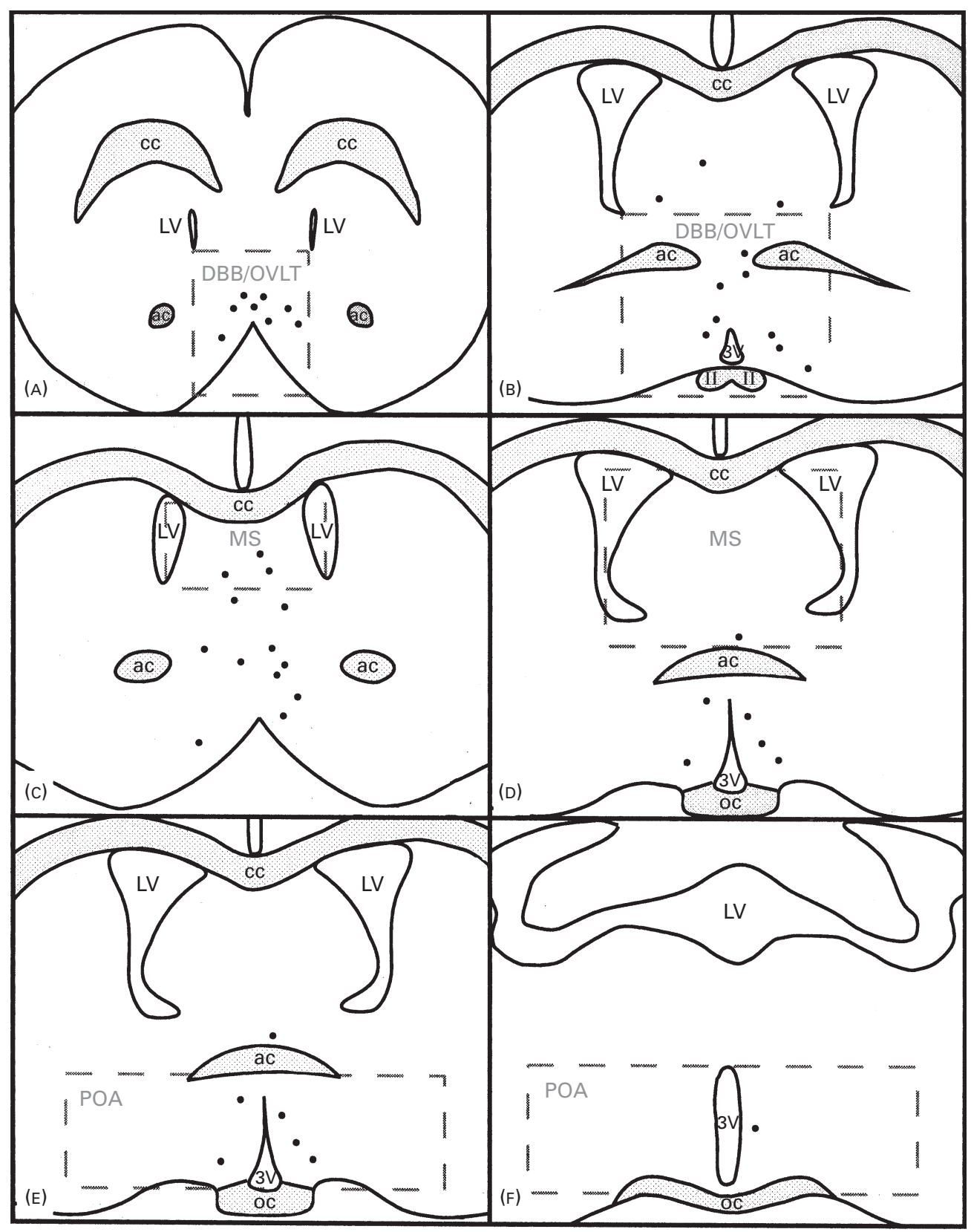

FIG. 1. Distribution of GnRH mRNA expressing cells in a representative adult male Syrian hamster within the DBB/OVLT (A, B), MS (C, D), and POA (E, F). The rostral extent of these anatomical boundaries is located in the left column (A, C, E) and the caudal extent in the right column (B, D, F). Filled circles represent the location of cells expressing GnRH mRNA. Abbreviations: II, optic nerve; 3V, third ventricle; ac, anterior commisure; cc, corpus callosum; DBB/OVLT, diagonal band of Broca/organum vasculosum of the lamina terminalis; LV, lateral ventricle; MS, medial septum; oc, optic chiasm; POA, preoptic area. 


\section{Pubertal Increase in GnRH mRNA}

testis, and seminal vesicle weights) and endocrine (plasma testosterone concentration) measures, as well as the mean number of labelled cells, and labelling intensity (area occupied by silver grains) per cell within each anatomical region. In a second statistical analysis, the grain density from all cells within the DBB/OVLT, MS, and POA for each age group was used to generate a frequency distribution. A comparison was then made between the frequency distributions of prepubertal and postpubertal males for each anatomical region using the nonparametric Kolmogorov-Smirnov two sample test (12). $\mathrm{P} \leqslant 0.05$ was the criterion for significance for all statistical tests.

\section{Results}

\section{Physical and endocrine measures}

Compared to 56-day-old postpubertal males, prepubertal 21-day-old male hamsters exhibited significantly lower body $(29.32 \pm 1.35 \mathrm{~g}$ vs $118.72 \pm 4.76 \mathrm{~g})$, paired testis $(0.11 \pm 0.02 \mathrm{~g}$ vs $2.70 \pm 0.22 \mathrm{~g})$, and seminal vesicle weights $(0.006 \pm$ $0.001 \mathrm{~g}$ vs $0.244 \pm 0.017 \mathrm{~g}$ ). In addition, circulating levels of testosterone were significantly lower in prepubertal $(0.21 \pm 0.07 \mathrm{ng} / \mathrm{ml})$ compared to postpubertal males $(3.55 \pm 0.65 \mathrm{ng} / \mathrm{ml})$.

\section{GnRH $m R N A$}

In-situ hybridization using an ${ }^{35} \mathrm{~S}$-labelled antisense riboprobe against hamster $\mathrm{GnRH}$ produced discrete labelling in brain regions consistent with the location of $\mathrm{GnRH}$ cell bodies revealed by immunocytochemistry $(6,7)$. Figure 1 illustrates the distribution of labelled cells throughout the forebrain of a representative adult male hamster. GnRH mRNA expressing cells were predominantly clustered along the midline of the septo-hypothalamic region. These cell bodies extended as far rostral as the tenia tecta and as far caudal as the posterior extent of the POA. In addition, cells expressing GnRH mRNA were occasionally located in the cingulate cortex. Previous reports from this laboratory have demonstrated that $>90 \%$ of the total number of GnRH-ir cells reside within 3 brain regions: the DBB/OVLT, MS, and POA (7). The anatomical boundaries for these three operationally defined brain regions are illustrated in Fig. 1, and quantification of GnRH mRNA expression was confined to these areas. Within these three regions, the majority of GnRH mRNA expressing cells was located in the DBB/OVLT ( $63 \%$ of total analysed cells), the MS contained fewer cells ( $24 \%$ of total analysed cells), and small numbers of cells were found diffusely throughout the POA and more caudal hypothalamic regions (13\% of total analysed cells). An example of specific labelling within the MS is illustrated in Fig. 2. As a test for specificity of our antisense riboprobe, tissue sections were incubated with an ${ }^{35}$ S-labelled sense probe generated against the same strand of DNA. No specific hybridization above background occurred with this probe.

To assess quantitative changes in GnRH mRNA expression during pubertal development, comparisons were made in the number of $\mathrm{GnRH}$ cells and the relative labelling intensity of these cells between prepubertal and postpubertal males. No age differences were observed in any anatomical region in the number of labelled GnRH mRNA cells (Fig. 3A). However, the intensity of labelling varied as a function of age. In all areas, there was a trend for greater mean area occupied by

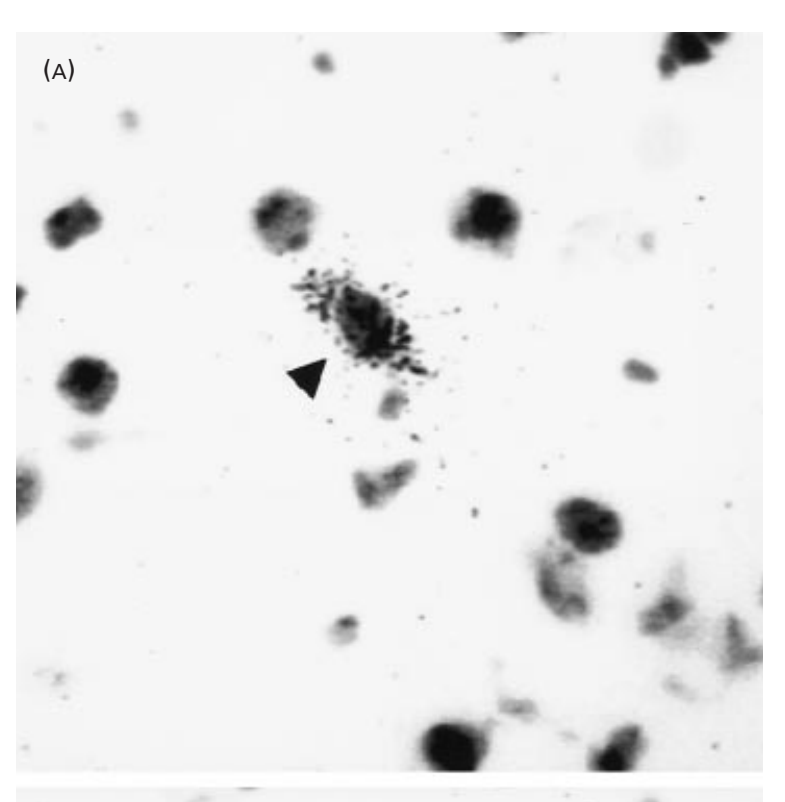

(B)

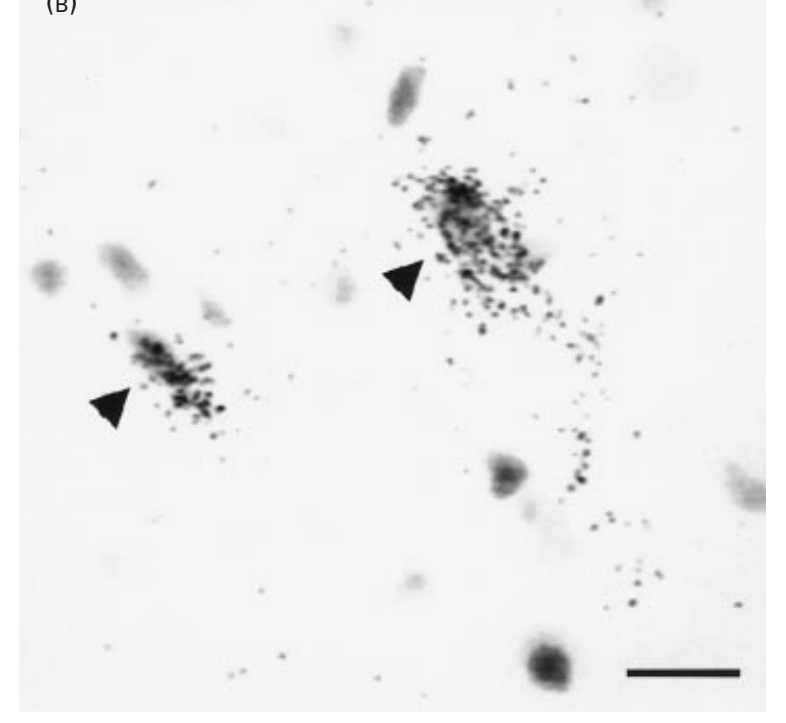

FIG. 2. Brightfield photomicrographs of the medial septum in a representative juvenile (21 day) (A) and adult (56 day) (B) male hamster after insitu hybridization for GnRH mRNA. Arrowheads indicate cells in which silver grains were $\geqslant 5 \times$ background. Scale bar $=10 \mu \mathrm{m}$.

silver grains in postpubertal compared to prepubertal males (Fig. 3B). However, statistical significance was reached only in the DBB/OVLT, where the silver grain area was approximately $1.5 \times$ greater in postpubertal compared to prepubertal animals $\left(10.71 \pm 1.31 \mu \mathrm{m}^{2}\right.$ vs $7.25 \pm 1.41 \mu \mathrm{m}^{2}$, respectively). Furthermore, no significant differences were observed in the mean area of the Nissl stained cells in any brain region across age groups (data not shown). A second analysis compared prepubertal and postpubertal frequency distributions of the area occupied by silver grains for all labelled cells. The Kolmogorov-Smirnov two sample test (10) revealed significant differences between the two frequency distributions in all three regions analysed $(\mathrm{P} \leqslant 0.05$, Fig. 4$)$. Closer examination of the distribution of cells in these regions revealed a shift to 
(A)

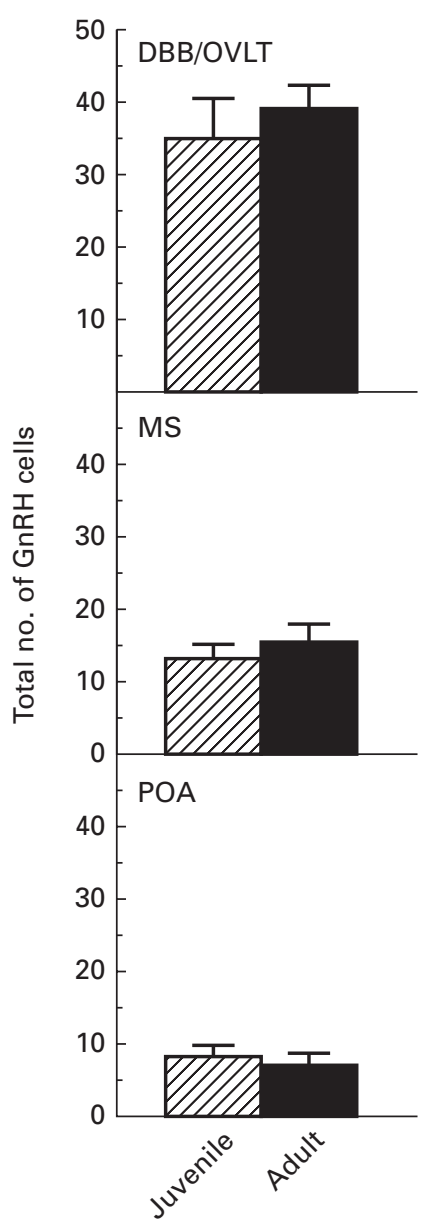

(B)

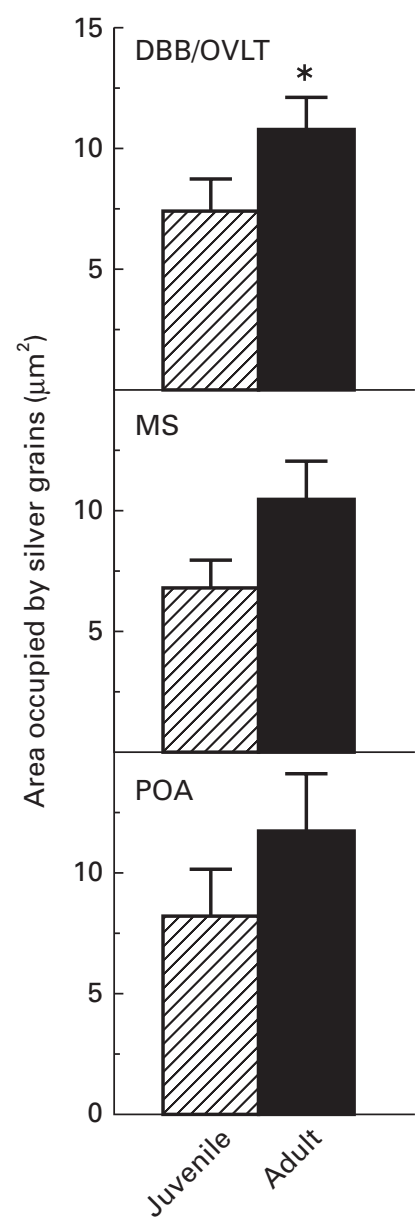

FIG. 3. (A) No difference in the total number of GnRH mRNA expressing cells $\geqslant 5 \mathrm{X}$ background in the DBB/OVLT, MS, or POA of juvenile and adult male hamsters. (в) Pubertal increase in the area occupied by silver grains (grain density) in the DBB/OVLT but not the MS or POA of adult male hamsters. *Significant difference between juvenile and adult males $(\mathrm{P} \leqslant 0.05)$.

the right in the postpubertal population of cells, which indicated an increased number of $\mathrm{GnRH}$ neurones with higher grain densities per cell.

\section{Discussion}

Results of this study demonstrate a pubertal increase in GnRH mRNA specifically manifested as an increase in labelling intensity in the DBB/OVLT, MS, and POA. This pubertal increase in GnRH mRNA is revealed as a significant increase in overall average grain density in the DBB/OVLT, and a shift to the right in the frequency distributions of grain density for neurones in all regions examined. One interpretation of these data is that the pubertal increase in GnRH mRNA is indicative of an overall increase in protein synthesis and subsequent release of $\mathrm{GnRH}$ from neurones in all regions of the brain. However, these reults must be reconciled with our previous observation that the pubertal decrease in $\mathrm{GnRH}$-ir was brain region specific, i.e. it was demonstrable

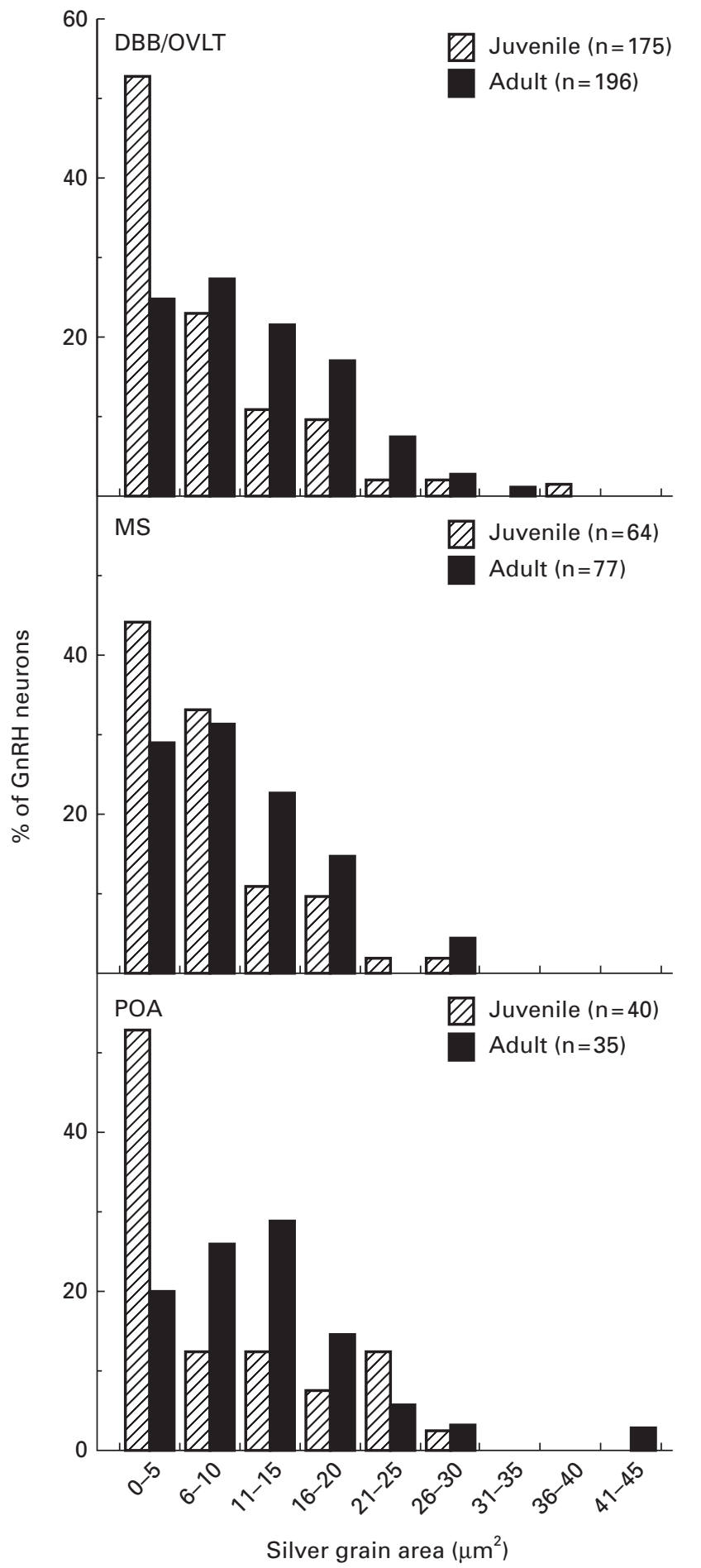

FIG. 4. Frequency distributions between juvenile and adult males for the area occupied by silver grains (grain density) for all labelled neurones within the DBB/OVLT, MS, and POA. Statistical analyses revealed that the distributions were significantly different in all three regions. Numbers in parentheses indicate the number of analysed cells.

only in the DBB/OVLT and MS, but not in POA (7). The pubertal increase in GnRH mRNA in the DBB/OVLT and MS in the present experiment does indicate that the pubertal decrease in GnRH-ir in these two regions likely reflects 


\section{Pubertal Increase in GnRH mRNA}

decreased somal stores of protein secondary to increased release of GnRH from these cells. Exactly how levels of GnRH mRNA relate to protein synthesis and release is not completely understood. The fact that GnRH mRNA increased within the POA in the absence of a decrease in GnRH-ir suggests that the relationships among transcription, translation, and peptide release are different within the DBB/OVLT and MS in comparison to the POA. Collectively, our immunocytochemistry and in-situ hybridization studies argue for differences among GnRH neurones in different brain regions, but the various populations of $\mathrm{GnRH}$ neurones do not appear to be distinguishable on the basis of pubertal changes in GnRH mRNA alone.

Techniques used in this experiment can not determine whether the pubertal increases in GnRH mRNA in the hamster brain result from an increase in GnRH transcription or a change in mRNA stability. However, in the female rat, pubertal increases in cytoplasmic GnRH mRNA are not accompanied by increases in primary transcript (13), suggesting that the elevation in GnRH mRNA is due to a posttranscriptional mechanism such as an increase in GnRH mRNA stability or a decrease in the degradation of GnRH mRNA. Additional studies are required to determine if the pubertal increase in GnRH mRNA in the male hamster is due to a post-transcriptional mechanism or increased GnRH transcription.

This pubertal increase in GnRH mRNA expression observed in the male hamster is consistent with observations in other species, including the male ferret and both the male and female rat $(9,13-15)$. However, other work suggests that GnRH mRNA expression remains constant across pubertal development. Steiner and colleagues report no differences in the number of GnRH mRNA expressing cells (16) or the amount of GnRH message/cell (17) in any area of the brain between prepubertal and adult male rats. These results are consistent with observations in the current study that the number of GnRH mRNA expressing neurones does not change with puberty. However, technical differences between the present study and those of Steiner and colleagues may explain the disparity of the message/cell results. For example, the GnRH oligonucleotide probes utilized in Wiemann et al. 1989 (17) could be less sensitive compared to the cRNA riboprobes used in the present study, and might not have allowed one to detect subtle changes in the amount of mRNA/cell (10). Furthermore, the digoxigenin-labelled GnRH cRNA probes utilized in Rossmanith et al. 1994 (16) would not allow for quantification of the amount of mRNA/cell.

Results from the present study raise the question as to whether specific subpopulations of GnRH neurones in the hamster are activated for particular events requiring enhanced $\mathrm{GnRH}$ release such as puberty, seasonal activation of the hypothalamic-pituitary-gonadal axis, or the preovulatory $\mathrm{LH}$ surge. Experiments from other laboratories indicate that $\mathrm{GnRH}$ neurones within the hamster DBB and MS are selectively influenced by photoperiod and estrous cyclicity. For example, a four week exposure to short-day photoperiods results in decreased gonadotropin secretion and changes in both the number of GnRH-ir and GnRH mRNA expressing cells within the DBB and MS, but not the POA $(18,19)$.
Furthermore, in the female hamster, GnRH neurones only within the DBB and MS express Fos in association with the preovulatory LH surge (20), suggesting separate 'surge' populations of GnRH neurones. Results from the present study suggest that puberty in the hamster does not selectively activate subpopulations of $\mathrm{GnRH}$ neurones, but instead causes a systemwide increase in GnRH gene expression. However, these differences might be explained by differences between puberty and photoperiodic and estrous cyclicity changes, or the regional regulation may not occur at the level of gene expression but instead at the level of protein translation or release. Additional studies are required to fully understand the relationship between gene expression and release of $\mathrm{GnRH}$, and how this might be regulated differently by various intrinsic and extrinsic stimuli in different regions of the brain.

In conclusion, results from this study suggest that neurones within the DBB/OVLT, MS, and POA all show an increase in GnRH mRNA as a result of the pubertal change in responsiveness to steroid negative feedback. Taken together with our earlier immunocytochemical data, the relationship between changes in transcription, translation, and release appears to be different within the DBB/OVLT and MS compared to the POA. One hypothesis for pubertal maturation is that neuronal circuits are remodeled so that testosterone and/or its metabolites exert different influences on particular populations of GnRH neurones before and after puberty. If the pubertal decrease in steroid negative feedback regulation of GnRH neurones is of varying degrees in the $\mathrm{DBB} / \mathrm{OVLT}, \mathrm{MS}$, and POA, then the relative contribution of these GnRH neurones to the pubertal increase in gonadotropin secretion may not be identical. Additional experiments and approaches will be necessary to sort the interaction between pubertal development of the nervous system and brain region specific steroid regulation of GnRH neurones.

\section{Acknowledgements}

We would like to thank Dr Heiko Jansen for the donation of the Syrian hamster GnRH cDNA and Mr Nathaniel Nonoy and Ms Anne Marie Wissman for their valuable technical assistance. This work was supported by NIH HD26483 and NSF IBN96-02169.

Accepted 9 March 1999

\section{References}

1 Sisk CL, Turek FW. Developmental time course of pubertal and photoperiodic changes in testosterone negative feedback on gonadotropin secretion in the golden hamsters. Endocrinology 1983; 112: 1208-1216.

2 Vomachka AJ, Greenwald GS. The development of gonadotropin and steroid hormone patterns in male and female hamsters from birth to puberty. (1979). Endocrinology 1979; 105: 960-966.

3 Foster D. Puberty in the sheep. In: Knobil E, Neill J. eds. The Physiology of Reproduction. New York: Raven Press, 1994: 411-454.

4 Sisk CL. Evidence that a decrease in testosterone negative feedback mediates the pubertal increase in luteinizing hormone pulse frequency in male ferrets. Biol Reprod 1987; 37: 73-81.

5 Silverman AJ, Livne I, Witkin JW. The gonadotropin-releasing hormone (GnRH), neuronal systems: immunocytochemistry and in situ hybridization. In Knobil E, Neill J. eds. The Physiology of Reproduction. New York: Raven Press, 1994: 1683-1709.

6 Lehman MN, Newman SW, Silverman AJ. Luteinizing hormone- 
releasing hormone in the vomeronasal system and terminal nerve of the hamster. Ann New York Acad Sciences 1987; 519: 229-240.

7 Richardson HN, Romeo RD, Sisk CL. Regional changes in GnRH immunoreactivity with puberty. Brain Res 1999; 817: 232-235.

8 Tang YP, Sisk CL. LHRH in the ferret: pubertal decrease in the number of immunopositive neurons. Peptides 1992; 13: 241-247.

9 Tang YP, Kashon ML, Sisk CL. Brain region-specific regulation of luteinizing hormone-releasing hormone messenger ribonucleic acid in the male ferret: interactions between pubertal maturation and testosterone. Endocrinology 1997; 138: 4740-4747.

10 Schafer MKH, Herman JP, Watson SJ. In situ hybridization histochemistry. In: London E. ed. Imaging Drug Action in the Brain. Boca Raton: CRC Press, 1993: 337-378.

11 Bowers G, Cullinan WE, Herman JP. Region-specific regulation of glutamic acid decarboxylase (GAD) mRNA expression in central stress circuits. J Neuroscience 1998; 18: 5938-5947.

12 Sokal RR, Rohlf FJ. Biometry: the Principles and Practice of Statistics in Biological Research. New York: W.H. Freeman, 1981.

13 Gore AC, Wu TJ, Rosenberg JJ, Roberts JL. Gonadotropin-releasing hormone and NMDA receptor gene expression and colocalization change during puberty in female rats. J Neurosci 1996; 16: 5281-5289.

14 Dutlow CM, Rachman J, Jacobs TW, Millar RP. Prepubertal increases in gonadotropin-releasing hormone mRNA, gonadotropin-releasing hormone precursor, and subsequent maturation of precursor processing in male rats. J Clin Investigation 1992; 90: 2496-2501.

15 Jakubowski M, Blum M, Roberts JL. Postnatal development of gonadotropin-releasing hormone and cyclophilin gene expression in the female and male rat brain. Endocrinology 1991; 128: 2702-2728.

16 Rossmanith WG, Marks DL, Clifton DK, Steiner RA. Induction of galanin gene expression in gonadotropin-releasing hormone neurons with puberty in the rat. Endocrinology 1994; 135: 1401-1408.

17 Wiemann JN, Clifton DK, Steiner RA. Pubertal changes in gonadotropin-releasing hormone and proopiomelanocortin gene expression in the brain of the male rat. Endocrinology 1989; 124: 1760-1767.

18 Ronchi E, Aoki C, Krey LC, Pfaff DW. Immunocytochemical study of GnRH and GnRH-associated peptide in male Syrian hamsters as a function of photoperiod and gonadal alterations. Neuroendocrinology 1992; 55: 134-145.

19 Ronchi E, Krey LC, Pfaff DW. Steady state analysis of hypothalamic GnRH mRNA levels in male Syrian hamsters: influences of photoperiod and androgen. Neuroendocrinology 1992; 55: 146-55.

20 Berriman SJ, Wade GN, Blaustein JD. Expression of Fos-like proteins in gonadotropin-releasing hormone neurons of Syrian hamsters: effects of estrous cycles and metabolic fuels. Endocrinology 1992; 131: 2222-2228. 